\title{
Kollaasista montaasiin, taidemuodosta toiseen
}

Magda Dragu 2020. Form and Meaning in Avant-Garde Collage and Montage. New York: Routledge, 226 s. ISBN 978-0-367-32254-0 (painettu), ISBN: 978-0-42931755-2 (e-kirja). https://doi.org/10.4324/9780429317552

Magda Dragun väitöskirjaan perustuva monografia on teoreettisesti jäsennelty ja ansiokas katsaus kollaasin ja montaasin historiaan ja näiden taidemuotojen rooliin viime vuosisadan alun avantgarde-liikkeissä. Teoksen käynnistää opinnäytteelle tyypillinen ja hieman raskas teoreettinen johdanto. Teoriasta päästään kuitenkin nopeasti konkreettisiin ja huolellisesti toteutettuihin historiallisiin teosanalyyseihin, joissa hyödynnetään johdannossa esiteltyä teoria-apparaattia. Intermediaalisuus ja sen teoria näyttelevätkin teoksessa keskeistä osaa, sillä tekijä seuraa, miten kollaasi ja montaasi syntyivät ja kehittyivät vuosien 1920 ja 1930 välissä eri taidemuotojen - kuvataiteen, kirjallisuuden, valo- ja elokuvan - välisen vuorovaikutuksen tuloksena. Dragu kertoo, kuinka representaation tapoja kokeellisesti tutkineesta heterogeenisestä visuaalisesta kollaasista kehittyi tänä ajanjaksona selkeitä poliittisia viestejä välittänyt homogeeninen valokuvamontaasi. Intermediaalisuus tulee kuvaan muun muassa elokuvamontaasin (Eisenstein, Vertov) vaikutuksena valokuvamontaasiin. Tarkasteltavana ajanjaksona kokeiltiin kollaasi- ja montaasitekniikkaa myös musiikissa. Dragu toteaakin, että eräänlainen medium-sallivuus oli ominaista tuon ajan avantgardelle. Tällä hän tarkoittaa sitä, että tuolloin siirrettiin herkästi tekniikoita taidemuodosta toiseen.

Intermediaalisuuden historiaa käsittelevässä luvussa tekijä paljastaa formalistiset lähtökohtansa viitaten muun muassa Hanslickiin ja Wölffliniin. Painopiste on saksalaisessa ja anglosaksisessa perinteessä. Tosin Rousseaukin mainitaan, mutta hieman anakronistisesti tulkittuna: hänen näkemyksensä siitä, että musiikki imitoi kieltä todetaan ohimennen puutteelliseksi, ohittaen sen, että Rousseaun aikana musiikilla oikeasti pyrittiin ja jäljittelemään puhetta ja sen intonaatiota. Dragu kirjoittaa, että jos musiikki olisi kieli, niin puhtaasti instrumentaalinen musiikki kykenisi ilmaisemaan käsitteitä. Mutta Rousseau vertasikin musiikkia kieleen lähinnä siksi (kuten Hanslick myöhemmin), että sen ymmärtäminen vaatii, samoin kuin kielen ymmärtäminen, sitä hallitsevien sääntöjen ja kulttuurin ymmärtämistä. Rousseaun, kuten myös hänen nuoruudenystäviensä Condillacille ja Diderotälle asian ydin nimenomaan oli, että musiikin sisältö ei ollut käsitteellistä ja täsmällistä kuten puhutun kielen vaan pikemminkin sukua eleille ja intonaatiolle sekä niiden epämääräi- 
sille merkityksille. ${ }^{1}$

Formalistisesta teoriataustasta huolimatta Dragu tähtää kuitenkin samalla, kuten otsikostakin käy ilmi, merkityksien tuottamisen tutkimiseen, siihen millaisia merkityksiä kollaaseilla ja montaaseilla on pyritty tuottamaan ja miten.

\section{Avantgarden VisuaAliset, Kielelliset Ja MUSiIKILliset KOLLAASIT}

Dragu aloittaa tarinansa Picasson kollaaseista vuosilta 1912-1914. Näissä maalauksiin oli liitetty käytetylle välineelle, mediumille, vieraita elementtejä, kuten sanomalehtileikkeitä tai nuotteja, jotka hyppäsivät ulos maalauksen illusorisesta kolmiulotteisesta tilasta todelliseen tilaan ja laajensivat samalla maalaustaiteen ekspressiivisiä mahdollisuuksia. Samalla tavalla Max Ernstin kivipiirroksista kootut romaanikollaasit rikkoivat visuaalisen kerronnan konventiota. Dragu analysoi myös runoilijoiden kuten Apollinairen, Marinettin, Schwittersin ja Tzaran kielellisiä kollaaseja.

Varhaisen avantgarden visuaalisista ja kielellisistä kollaaseista Dragu siirtyy musiikillisiin kollaaseihin. Musiikillisen kollaasin tiukan mär̈itelmän, johon tekijä nojautuu, mukaan kollaasin elementtien pitää säilyttää oma identiteettinsä. Kollaasin heterogeeninen alkuperä tulee olla kuulijan havaittavissa. Pelkkä toisen sävellyksen siteeraaminen niin, että sitaatti on integroitu kappaleen harmoniseen ja rytmiseen rakenteeseen, ei tee teoksesta kollaasia. Tämän tiukan heterogeenisen kollaasin määritelmän täyttävät eräät Charles Ivesin, Eric Satien ja Igor Stravinskyn 1920-luvulla säveltämät teokset. Nämä teokset eivät siis pelkästään lainaa tai siteeraa muita sävellyksiä tai ole kollaaseja sanan löyhässä, metaforisessa mielessä. Niissä ovat havaittavissa visuaalisen kollasin genrerajat ylittävät formaaliset piirteet. Selkeitä tapauksia ovat esimerkiksi Ivesin 1912-1913 sävelletty Fourth of July, jossa on käytetty populaareja isänmaallisia lauluja ja tanssisävelmiä tai Holidays Symphonyn ensimmäinen osa Washington's Birthday, jossa on niin ikään lainattu Ivesin lapsuudesta tuttua sotilasmusiikkia ja virsiä. Kun nämä elementit ovat kuulijalle tuttuja, niistä tulee viittauksia sävellyksen ulkopuoliseen todellisuuteen. Vaikka Ivesin kollaasit vastaavat muodollisesti visuaalisia kollaaseja, kyse ei kuitenkaan tässä tapauksessa ole visuaalisten kollaasien vaikutuksesta hänen musiikkiinsa, vaan hän tuntuu tehneen keksintönsä itsenäisesti.

Valtameren toiselta puolelta esimerkit musiikillisista kollaaseista sen sijaan löytyvät Eric Satien ja Igor Stravinskyn tuotannosta. Satien balettimusiikki Parade (1917) ei kontekstiltaan ole kaukana Picassosta ja tämän visuaalisista kollaaseista. Picasso nimittäin suunnitteli teoksen lavasteet ja puvustuksen. Satien sävellyksessä lainattiin

1 Ks. Downing A. Thomas: Music and the origins of language: theories from the French Enlightenment. Cambridge: Cambridge University Press, 1995. https://doi.org/10.1017/CBO9780511582608 
kabaree- ja sirkusmusiikkia. Lisäksi Satie lainasi teemoja sellaisilta säveltäjiltä kuin Debussy tai Stravinsky. Picasson maalauksiin liimatut ei-kuvalliset elementit tulevat herkästi mieleen Satien tavasta jäljitellä erilaisia hälyääniä kuten kirjoituskoneen, pistoolin, sireenin tai arvontapyörän ääniä, ilman harmonista integraatiota.

Kollaaseina voidaan pitää myös joitain Stravinskyn tapoja integroida sävellyksiinsä kansansävelmiä, katulauluja tai valsseja 1910-luvun baleteissaan Tulilintu, Petruška, Kevätubri ja Hä̈̈. Stravinskyn sävellystekniikka on liitetty kollaasiin myös toisella tavalla. Stravinskyn musiikki kostuu usein, esimerkiksi Kevätuhrissa, eräänlaisista "blokeista", mutta tämä ei vielä välttämättä tee niistä kollaaseja tiukasti tulkittuna, sillä nämä rakennuspalikat on integroitu toisiinsa (esim. motiivit harmonisesti suhteutettu toisiinsa). Sen sijaan Stravinskyn tapa lisätä sävelmiä muuten itsenäisiin sävellyksiin vastaa paremmin kollaasin käsitettä etenkin tapauksissa, joissa käsikirjoitus osoittaa, että ne on lisätty jälkikäteen, kuten on laita teoksen Sinfonioita puhaltimille (1920/1947) koraalijaksossa. Näiden kolmen kollaasiin viittaavan tekniikan vuoksi Dragu katsoo, että termiä 'kollaasi' voidaan soveltaa Stravinskyn musiikkiin. Dragun esimerkit poikkeavat sävellyksiin sisältyvistä sitaateista sikäli, että niissä lainattu materiaali on yleensä peräisin populaarimusiikista, ja näin ne saavat aikaan kollaasille ominaisen materiaalien heterogeenisuuden.

\section{KollaAsi Ja MONTAASI}

Dragun mukaan fotomontaasi kehittyi visuaalisista kollaaseista intermediaalisena siirtymänä. Tämän tuloksena syntyi ensin 'heterogeeninen' fotomontaasi, jota edustivat dada-kollaasit. Nämä heijastelivat yleistä yhteiskuntakriittistä asennetta, mutta niissä ei ollut selkeästi tunnistettavaa poliittista "viestiä". 'Homogeeninen' fotomontaasi sen sijaan ilmentää kommunikatiivisempaa asennetta, ja niissä on usein tunnistettavissa selkeitä esimerkiksi poliittisia kannanottoja. Siirtymään myötävaikuttivat Dragun mukaan Sergei Eisensteinin, Dziga Vertovin ja muiden kehittämät elokuvamontaasin tekniikat, joissa kuvamontaasilla yritettiin välittää käsitteellisiä merkityksiä. Näin tapahtuu esimerkiksi Eisensteinin Panssarilaiva Potemkinissa, jossa Odessan portailla tapahtuneen armeijan väkijoukkoon kohdistaman verilöylyn ja sen merimiehissä herättämän reaktion perään näytetään kolme still-kuvaa: nukkuva leijona, heräävä leijona ja herännyt leijona. Kuvasarjan on helppo lukea viittaavan kansan heräämisen tsaarin valtaa vastaan.

Yksi Dragun monografian keskeisiä teesejä ja ansioita onkin kollaasin ja montaasin selkeä erottelu. Tämä erottelu ei perustu käytettyyn tekniseen menetelmään vaan erityyppiseen viittauksen ja merkityksen luomiseen. Hänen mukaansa kollaasin ja montaasin erottaa se, että montaasi pyrkii välittämään katsojalle enemmän tai vähemmän selkeitä väitteitä todellisuudesta tai tiettyjen asiantilojen suotavuudesta. Eräänlaisen poikkeuksen tai välimuodon muodostavat Raoul Haussmanin foto- 
montaasit, jotka olivat muodoltaan mutteivat merkitykseltään homogeenisiä. Dragu analysoi kehitystä heterogeenisistä dada-kollaaseista homogeenisiin venäläisten konstruktivistien kollaaseihin, joissa korostui dadan kaoottisen anarkistisen pilkan sijasta selkeä yhteiskunnallinen ja poliittinen, kirjaimellisesti konstruktiivinen viesti.

\section{KiRJALLINEN JA MUSIIKILLINEN MONTAASI}

Dragun tarkastelemana jaksona montaasiperiaatetta ehdittiin soveltaa myös kirjallisuuteen ja musiikkiin. Kirjallisuudessa selkeimpiä esimerkkejä ovat Dos Passosin romaani Manhattan Transfer (1925) sekä U.S.A.-trilogia (1930-1936). Passos käytti montaasitekniikkaa kertomalla montaa tarinaa rinnakkain niin, että niiden väliset siirtymät mahdollistivat moraaliset kannanotot, ilman didaktista tai paternalistista kerrontaa. Toinen tunnettu esimerkki on Alfred Döbelnin Berlin Alexanderplatz, jossa on sekä kollaasin että montaasin elementtejä. Musiikilliset esimerkit montaasista löytyvät puolestaan Karlheinz Stockhausenin ja Pierre Schaefferin tuotannosta. Sikäli kuin Dragu katsoo formalistisen musiikkinäkemyksensä mukaan montaasin edellyttämän selkeän merkityksen olevan käytännössä mahdotonta, hänen esimerkkinsä ovatkin teoksia, joissa käsitteelliset merkitykset kiinnitettiin tekstin tai konkreettisten äänien kautta, kuten on laita Stockhausenin Gesang de Jünglingessa (1955-1956) tai Schaefferin teoksessa Étude aux chemins de fer (1948). Dragu toteaa samalla, että - musiikillisista montaaseista riippumatta - myös musiikillisia kollaaseja tehtiin edelleen 1960- ja 1970-luvilla.

Dragun teos tarjoaa selkeästi jäsennetyn tarinan kollaasi- ja montaasitekniikoiden kehityksestä viime vuosisadalla. Samalla se on suositeltavissa kaikille, jotka haluavat käyttää näitä käsitteitä tutkimuksessaan ja jotka haluavat tekstiinsä samaa käsitteellistä täsmällisyyttä ja ryhtiä kuin Dragun teoksessa. Itse kukin voi tietenkin jatkaa Dragun avaamia polkuja: tehdä lisää kiinnostavia erotteluja ja vaikka tutkia musiikin intermediaalisia ulottuvuuksia varhaisempien periodien tutkimuksen vaatimasta vähemmän formalistisesta näkökulmasta. Olettaisin, että musiikin intermediaalisuus todennäköisesti sai toisenlaisia ilmenemismuotoja aikoina, jolloin musiikki ei vielä ollut niin "puhdasta". 